\title{
Reassessment of Mycotoxin Productivity of Microdochium nivale in Japan
}

\author{
Takashi NAKAJIMA* and Shigeo NAITO*
}

\begin{abstract}
The reports about negation of mycotoxin productivity of Microdochium nivale (syn. Fusarium nivale) led us to reinvestigate Japanese isolates of $M$. nivale. Thirty isolates were collected from different district of Japan. These were from 5 species of gramineous plants in 1988-1993 and analyzed on their mycotoxin productivity within 2 years. Trials were conducted for combinations of medium (rice and wheat grain) with culture temperature $\left(0^{\circ} \mathrm{C}\right.$ and $\left.20^{\circ} \mathrm{C}\right)$. In addition, we examined samples inoculated artificially on cut-spikes of winter wheat and field samples of orchardgrass infested with $M$. nivale. As a result, we did not detect the known mycotoxins (deoxynivalenol, 3-acetyldeoxynivalenol, nivalenol, fusarenon-X, T-2 toxin, neosolaniol, zearalenone) in all trials. Mycelial growth temperature of Fusarium sp. strain Fn-2B, from which nivalenol was firstly isolated, was higher than that of M. nivale. Fn-2B was not pathogenic to winter wheat under snow.
\end{abstract}

(Received January 12, 1995 ; Accepted February 28, 1995)

Key words : Microdochium nivale, Fusarium nivale, mycotoxin, nivalenol.

\section{INTRODUCTION}

It is well documented in text books that Fusarium nivale (Fr.) Ces. is typical producer of trichothecenes mycotoxin. Nivalenol was first isolated from $F$. nivale isolate Fn-2B recovered from wheat head blight in Kumamoto Prefecture, Japan ${ }^{21)}$. Fusarenon and fusarenon-X were detected in the same isolate $e^{20,23,24)}$. Marasas et al. reexamined toxigenic strains of $F$. nivale in International Toxic Fusarium Reference Collection and reported that Fn-2B should be identified as Fusarium sporotrichioides Sherb. (W\&R, G, B, J) ${ }^{10,11)}$. They excluded trichothecene toxin formation from $F$. nivale with 1 exception of isolate NRRL3289, which produced a low level of deoxynivalenol $(1 \mu \mathrm{g} / \mathrm{g})$. However, Logrieco et al. could not confirm deoxynivalenol production of NRRL 32899). Classification of $F$. nivale isolate Fn-2B was controversial because of mutations due to periodic transfers over 25 years. Recently, the isolate have been noted as Fusarium sp. strain Fn-2B ${ }^{20}$.

An additional confusion is the change of nomenclature of the genus. $F$. nivale is now considered to be Microdochium nivale (Ces. ex Berl. \& Vog1.) Samuels \& Hallett and its teleomorph is Monographella nivalis (Schaffnit) E. Müiller ${ }^{2,3)}$

Chelkowski et $a l .{ }^{1)}$ and Ichinoe et $a l .{ }^{4)}$ reported that $M$. nivale did not produce mycotoxin in Poland and Japan, respectively. However, these previous studies examined only a few isolates and less attention had been paid to medium and culture conditions for mycotoxin productivity. Logrieco et $a l_{.}{ }^{9)}$ pointed out that it would be important to reevaluate strains of $M$. nivale for ability to produce mycotoxins because this species occurs commonly on wheat and grasses ${ }^{9}$.

The objects of this study were to reexamine mycotoxin productivity of Japanese isolates of $M$. nivale, taking account of source of isolates and culture conditions. Parts of this work have been reported previously in abstract $^{15)}$.

\section{MATERIALS AND METHODS}

Collection of Microdochium nivale in Japan. Thirty isolates of $M$. nivale were collected from different district of Japan (Table 1). The fungi were isolated from 5 species of gramineous plants in 19881993. Isolation sites were head blight, pink snow mold, foot rot, seed, and perithecia filling life cycle of $M$. nivale. The isolates were analyzed for mycotoxins within 2 years after isolation. Fusarium sp. Fn-2B and Fusarium graminearum R2118, which were provided from Science University of Tokyo, were used as positive controls of nivalenol ${ }^{20,23,24)}$ and deoxynivalenol ${ }^{5)}$ production, respectively.

Medium and culture conditions. The following 6 trials were conducted using combinations of media and incubation temperature. In trials 1 and 2, $300 \mathrm{ml}$ flask,

\footnotetext{
* Tohoku National Agricultural Experiment Station, Shimo-Kuriyagawa, Morioka, Iwate 020-01, Japan＼cjkstart東北農業試験場 地域基盤研究部
} 
containing $30 \mathrm{~g}$ polished rice grains which were previously immersed in $15 \mathrm{ml}$ deionized water for 3 hours, was autoclaved at $120^{\circ} \mathrm{C}$ for $20 \mathrm{~min}$. We used Fusariumfree wheat grain instead of rice in trials 3 and 4 . All isolates were incubated at $20^{\circ} \mathrm{C}$ for 14 days in trial 1 , at $0^{\circ} \mathrm{C}$ for 50 days in trial 2 , at $20^{\circ} \mathrm{C}$ for 14 days in trial 3 and $0^{\circ} \mathrm{C}$ for 50 days in trial 4 . Uninoculated media treated in the same way were used as negative controls. In trial 5 , 5 isolates of PSM-1, Me-1, 92-P-1, NK-93-8 and ARC2146 were inoculated artificially on cut-spikes of winter wheat at anthesis ${ }^{18)}$ and incubated at $20^{\circ} \mathrm{C}$ for 4 days in a moist chamber ${ }^{12)}$. In addition, we examined 3 field samples of orchardgrass (Dactylis glomerata L.) infested with pink snow mold collected in Iwate Prefecture.

Analysis for mycotoxins. Mycotoxins were examined by the method of Tanaka ${ }^{19)}$. Briefly, the samples were homogenized with acetonitrile-water $(3: 1, \mathrm{v} / \mathrm{v})$ and shaken for $30 \mathrm{~min}$ by an automatic shaker, and the aqueous acetonitrile extract was filtered. The filtrate was partitioned with n-hexane. The upper n-hexane layer was discarded. The ethanol was added to the aqueous acetonitrile and the mixture was evaporated to dryness under vacuum. The toxins were purified by column chromatography on Florisil. After derivatization by trimethylsilylating reagent, the amounts of seven mycotoxins (nivalenol, deoxynivalenol, 3-acetyldeoxynivalenol, fusarenon-X, T-2 toxin, neosolaniol, zearalenone) were estimated by gas-liquid chromatography (GLC). Operating conditions of the GLC analysis were similar to the method of Ueda et al. ${ }^{22)}$ with fused silica capillary column (Shimadzu HiCap CBP 1 column, $0.33 \mathrm{~mm} \mathrm{id} \times 25 \mathrm{~m}$ ). The detection limits were ranged from 0.1 to $0.2 \mu \mathrm{g} / \mathrm{g}$.

Mycelial growth. The mycelial growth rates were determined by placing each $9 \mathrm{~mm}$ mycelial disc on PDA (Potato Dextrose Agar, Difco) plate and incubating at $0-35^{\circ} \mathrm{C}$. The measurements of the radial mycelial growth lengths were taken every $24 \mathrm{hr}$ and the results were shown by the averages of 5 isolates in $M$. nivale and by the averages of 3 replications in Fusarium. sp. Fn-2B.

Pathogenicity under snow. Fusarium sp. Fn-2B and 9 isolates of $M$. nivale recovered from wheat head blight (Table 1) were tested for pathogenicity to winter wheat (Triticum aestivum L.) under snow. Seeds of cultivar Kitakamikomugi which is susceptible to pink snow mold ${ }^{13)}$ were sown in a plastic box $(350 \times 250 \times 60$ $\mathrm{mm}$ ) at a density of 20 plants in 1 box on 12 October 1992. The experiment consisted of 30 boxes in a completely randomized design including 10 isolates and 3

Table 1. Isolates of Microdochium nivale collected in Japan

\begin{tabular}{|c|c|c|c|}
\hline Isolate & Locality & Date & Source \\
\hline SII-3 & Shirataki, Hokkaido & May, 1990 & Wheat, pink snow mold \\
\hline PSM-5 & Bihoro, Hokkaido & Apr., 1992 & do. \\
\hline PSM-1 & Iwamizawa, Hokkaido & do. & do. \\
\hline Kaw-2 & Obihiro, Hokkaido & Jul., 1991 & Wheat, head blight \\
\hline $\mathrm{Me}-1$ & Memanbetu, Hokkaido & do. & do. \\
\hline Cn8937 & Kunneppu, Hokkaido & Jul., 1989 & Wheat, perithecia on lower stem \\
\hline FK-1 & Fukaura, Aomori & Jul., 1988 & Wheat, head blight \\
\hline TWY-6 & Towada, Aomori & May, 1991 & Orchardgrass, pink snow mold \\
\hline TWY-10 & do. & do. & Perennial ryegrass, pink snow mold \\
\hline TAK-91-1 & Takko, Aomori & do. & do. \\
\hline TAK-91-2 & do. & do. & do. \\
\hline OM-3 & Ichinohe, Iwate & Apr., 1991 & Wheat, pink snow mold \\
\hline OM-5 & do. & do. & Orchardgrass, pink snow mold \\
\hline 91-E4-2 & Morioka, Iwate & Jun., 1991 & Wheat, perithecia on lower stem \\
\hline 91-E4-5 & do. & do. & do. \\
\hline 91-E4-6 & do. & do. & do. \\
\hline $92-\mathrm{P}-1$ & do. & Jul., 1992 & Wheat, head blight \\
\hline $92-\mathrm{P}-5$ & do. & do. & do. \\
\hline $92-\mathrm{P}-8$ & do. & do. & do. \\
\hline $92-\mathrm{S}-1$ & do. & Oct., 1992 & Wheat, seed \\
\hline $92-\mathrm{S}-2$ & do. & do. & do. \\
\hline $92-\mathrm{S}-3$ & do. & do. & do. \\
\hline NK-93-8 & Kashiwazaki, Niigata & Apr., 1993 & Barley, pink snow mold \\
\hline NK-93-2 & do. & do. & do. \\
\hline MAFF101050 & Toyama & 1988 & Barley, head blight \\
\hline MAFF236681 & Nagano & 1992 & do. \\
\hline Т9149-1 & Chiba, Chiba & Dec., 1991 & Bentgrass, pink snow mold \\
\hline MAFF235733 & Ibaraki & 1991 & do. \\
\hline ARC2158 & Shimotsuma, Ibaraki & May 1990 & Barley, foot rot \\
\hline ARC2164 & Tsukuba, Ibaraki & do. & Wheat, head blight \\
\hline
\end{tabular}




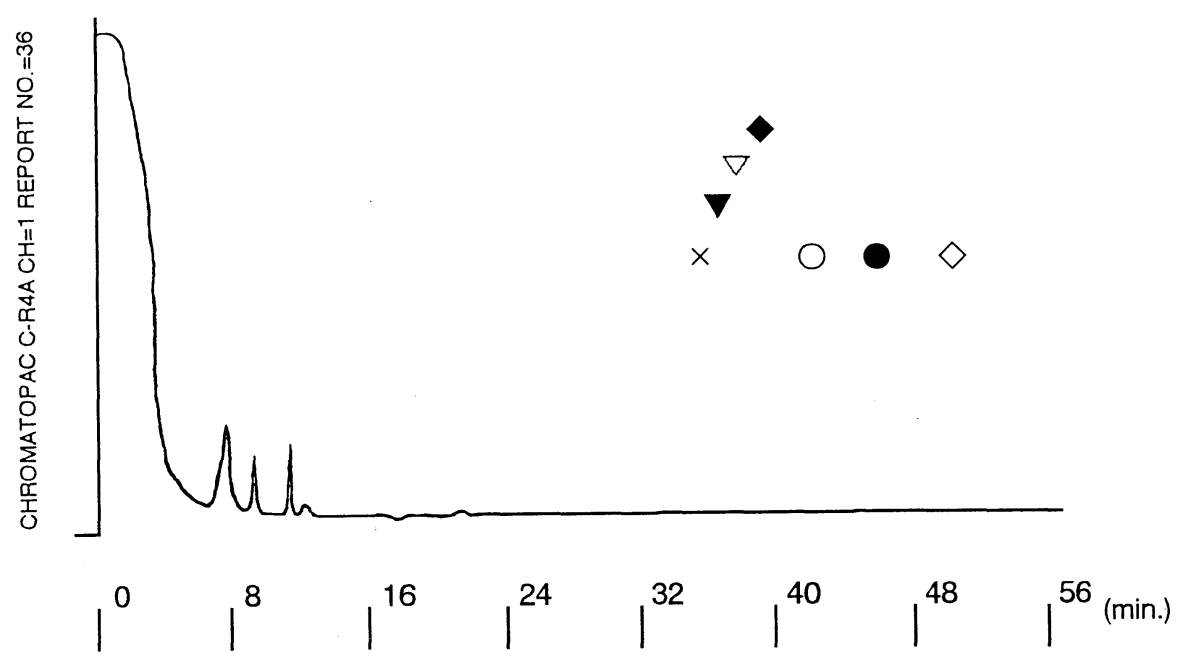

Fig. 1. Gas liquid chromatograms of metabolites by Microdochium nivale 92-P-1 produced in rice culture 14 days after inoculation at $20^{\circ} \mathrm{C}$. Retention times of standard mycotoxins are represented by $\times$ : deoxynivalenol, $\mathbf{\nabla}$ : 3 -acetyldeoxynivalenol, $\nabla$ : nivalenol, $\bullet$ : fusarenon-X, ०: T-2 toxin, $\bullet$ : neosolaniol, and $\diamond$ : zearalenone.

Table 2. Pathogenicity to winter wheat, cv. Kitakamikomugi, under snow of Fusarium sp. strain Fn-2B and isolates of Microdochium nivale recovered from wheat head blight

\begin{tabular}{lcc}
\hline \hline \multicolumn{1}{c}{ Isolate } & Plant survival $^{\mathrm{a})}$ & Disease index $^{\mathrm{b})}$ \\
\hline Fn-2B & $100.0 \mathrm{c}$ & $0.0 \mathrm{c}$ \\
Kaw-2 & $0.0 \mathrm{a}$ & $3.0 \mathrm{a}$ \\
Me-1 & $10.0 \mathrm{a}$ & $2.5 \mathrm{a}$ \\
FK-1 & $15.0 \mathrm{a}$ & $2.3 \mathrm{~b}$ \\
92-P-1 & $0.0 \mathrm{a}$ & $3.0 \mathrm{a}$ \\
92-P-5 & $33.3 \mathrm{~b}$ & $2.1 \mathrm{~b}$ \\
92-P-8 & $40.0 \mathrm{~b}$ & $1.8 \mathrm{~b}$ \\
MAFF101050 & $25.0 \mathrm{ab}$ & $2.2 \mathrm{~b}$ \\
MAFF236681 & $33.3 \mathrm{~b}$ & $1.9 \mathrm{~b}$ \\
ARC2164 & $10.0 \mathrm{a}$ & $2.8 \mathrm{a}$ \\
\hline
\end{tabular}

a) Following 70 days incubation under snow, the percent survival of plant and disease index were recorded.

b) Disease index is based on a $0-3$ scale where 0 , no visible injury; $1,50 \%$ of leaves green; 2 , only stems green; and $3,100 \%$ necrosis.

c) Values within a column followed by the same letter are not significantly different at $p=0.05$ as determined by Tukey-Kramer's multiple-range test.

replications. The boxes were set outdoors immediately after sowing till inoculation. Ten weeks after seeding (December 21), the naturally hardened plants with 2 to 3 tillers were artificially inoculated and covered with 50 $\mathrm{cm}$ snow. Inoculum of wheat bran-vermiculite medium ${ }^{13)}$ was spread on the soil surface at a level of $0.06 \mathrm{~g} / \mathrm{cm}^{2}$. The boxes were taken out after 90 days incubation under snow and transferred to a green house for recovery. After 2 weeks, we assessed visually degree of necrosis with a scale of $0-3$ where 0 , no visible injury; 1 , $50 \%$ of leaves green; 2 , only stems green; and 3, 100\% necrosis ${ }^{13)}$.

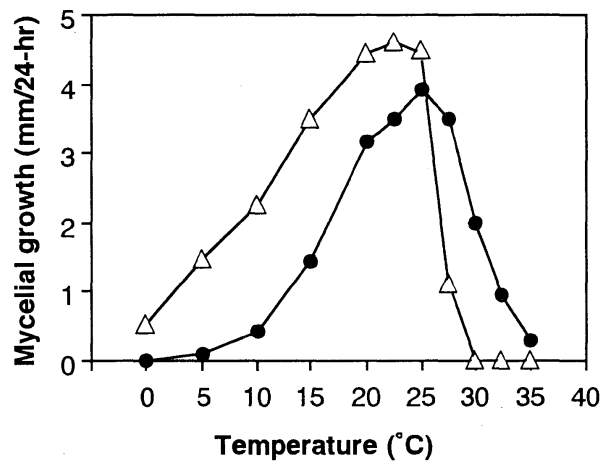

Fig. 2. Difference in mycelial growth rate at different temperatures between Fusarium sp. strain Fn2B (•) and Microdochium nivale $(\Delta)$.

\section{RESULTS}

\section{Mycotoxin productivity of Microdochium nivale collected in Japan}

One example of gas liquid chromatograms of extract from rice culture by $M$. nivale $92-\mathrm{P}-1$ incubated at $20^{\circ} \mathrm{C}$ is shown in Fig. 1. Retention times of 7 standard mycotoxins (deoxynivalenol, 3-acetyldeoxynivalenol, nivalenol, fusarenon-X, T-2 toxin, neosolaniol, zearalenone) were found in over $30 \mathrm{~min}$. No peaks in over 30 min were observed in all isolates under all trials which combine medium and culture conditions. We did not detect any mycotoxins in samples inoculated artificially on cut-spikes of winter wheat and field samples of orchardgrass infested with $M$. nivale. On the contrary, we confirmed production of nivalenol, deoxynivalenol, 3 -acetyldeoxynivalenol, fusarenon-X in positive controls.

Mycelial growth and pathogenicity under snow of Fusarium sp. strain Fn-2B

Fusarium sp. strain Fn-2B grew at temperatures rang- 
ing from 5 to $35^{\circ} \mathrm{C}$ (Fig. 2). The optimum growth temperature was $25^{\circ} \mathrm{C}$, little higher than that of $M$. nivale isolates. $M$. nivale could grow at $0^{\circ} \mathrm{C}$, but not over $30^{\circ} \mathrm{C}$ and its growth rates under $15^{\circ} \mathrm{C}$ were much higher than that of the Fusarium sp. strain Fn-2B.

All isolates of $M$. nivale recovered from head blight were highly pathogenic to wheat under snow (Table 2). However, Fusarium sp. strain Fn-2B did not kill wheat plants nor cause any lesions under snow.

\section{DISCUSSION}

In previous reports ${ }^{1,4,9-11)}$ dealing with mycotoxin productivity of $M$. nivale, a few and old isolates have been tested. Rice medium, peptone-supplemented Czapec medium and incubation at $25-27^{\circ} \mathrm{C}$ were reported as good environment factors affecting mycotoxin production by using Fusarium sp. strain Fn-2B ${ }^{23)}$. These culture conditions were unfavorable for real $M$. nivale. Therefore, we set up six trials for medium and culture conditions on the basis of ecological aspects of $M$. nivale. Optimum temperature of $M$. nivale for infection causing wheat head blight is $20^{\circ} \mathrm{C}^{14)}$ and pink snow mold prevails under snow with temperature of near $0^{\circ} \mathrm{C}^{6}$. However, we could not detect any trichothecene mycotoxin and zearalenone reported in Fusarium spp. by other researchers in all trials.

$M$. nivale is a cryophilic fungus and a causal pathogen of pink snow mold in winter wheat ${ }^{6)}$. In previous articles $^{1,4,9-11)}$ on mycotoxins, pathogenicity of Fusarium sp. strain Fn-2B under snow has not been studied. We confirmed that all isolates of $M$. nivale recovered from head blight of wheat and barley have pathogenicity to wheat plants under snow ${ }^{8,16)}$, whereas Fusarium sp. strain Fn-2B was not pathogenic under snow and temperature response of mycelial growth of Fn-2B was different from that of $M$. nivale. Recently, Marasas et $a l .^{10,11)}$ reported that $\mathrm{Fn}-2 \mathrm{~B}$ should be identified as $F$. sporotrichioides, while Ichinoe ${ }^{4)}$ noted Fn-2B was like $F$. tricinctum for his morphological observation. Our findings only supports that Fusarium sp. strain Fn-2B differs from $M$. nivale. Neither conidia nor any another spores were formed in our studies (Nakajima, unpublished). Correct identification might be impossible because the isolate was not maintained under optimal condition and periodical transfers over 25 years.

We conclude from this study that $M$. nivale in Japan does not produce any of the known mycotoxins. In northern Japan, the Hokkaido and the Tohoku district, $M$. nivale predominates when the summer is cool and wet $^{7,8,16,25)}$. However, other fusaria of $F$. graminearum, $F$. sporotrichioides, $F$. poae, etc., affect wheat head in normal climate year ${ }^{4,17}$. We should continue to pay attention to mycotoxin contamination even in northern Japan.

The authors thank to Dr. Y. Ueno, Science University of Tokyo and Ms. M. Kayaba, Hokkaido Prefectural Central
Agricultural Experiment Station and Dr. T. Takeuchi, Chiba Prefectural Agricultural Experiment Station and Dr. S. Koizumi, Aichi Prefectural Agricultural Research Center Mountainous Region Experiment Farm and Dr. T. Tsutsumi, Hokuriku National Agricultural Experiment Station and Dr. T. Kobayashi, Forest Development Technological Institute, for providing isolates of $M$. nivale and Dr. K. Tanaka, National Food Research Institute, for his technical advice of mycotoxin analysis and Dr. Y. Sugiura, Science University of Tokyo, for his helpful suggestions of literatures.

\section{Literature cited}

1. Chelkowski, J., Golinski, P., Perkowski, J., Visconti, A., Rakowska, M. and Wakulinski, W. (1991). Toxinogenicity of Microdochium nivale (Fusarium nivale) isolates from cereals in Poland. Mycotoxin Res. $7: 140-$ 145.

2. Gams, W. (1989). Taxonomy and nomenclature of Microdochium nivale. In Fusarium Mycotoxins, Taxonomy and Pathogenicity (Chelkowski, J. ed.), Elsevier Science Pub., Amsterdam, pp. 195-198.

3. Gams, W. and Muller, E. (1980). Conidiogenesis of Fusarium nivale and Rhynchosporium oryzae and its taxonomic implications. Neth. J. Plant Pathol. 86 : 4553.

4. Ichinoe, M., Uchiyama, S., Amano, R. and Kurata, H. (1985). Trichothecene-producing Fusarium in barley and wheat in Japan. In Trichothecenes and Other Mycotoxins (Lacey, J. ed.), John Wiley \& Sons Ltd. New York, pp. 21-32.

5. Ishii, K., Sato, H. and Ueno, Y. (1985). Production of 3 -acetyldeoxynivalenol in shake culture. Mycotoxin Res. $1: 19-24$

6. Jamalainen, E.A. (1974). Resistance in winter cereals and grasses to low temperature parasitic fungi. Annu. Rev. Phytopathol. 12 : 281-302.

7. Koizumi, S., Kato, H., Yoshino, R., Hayashi, N. and Ichinoe, M. (1991). Distribution of causal fusaria of wheat and barley scab in Japan. Ann. Phytopathol. Soc. Jpn. $57:$ 165-173.

8. Koizumi, S., Kato, H., Yoshino, R., Komada, H., Umehara, Y., Ichinoe, M. and Hayashi, N. (1993). Studies on the pathogens and epidemiology of wheat and barley scab. Bull. Natl. Agric. Res. Cent. 23 : 1-104 (in Japanese with English summary).

9. Logrieco, A., Peterson, S.W. and Bottalico, A. (1991). Reexamination of the taxonomic disposition of and deoxynivalenol production by Fusarium nivale NRRL 3289. Mycologia 83 : 367-370.

10. Marasas, W.F.O., Nelson, P.E. and Toussoun, T.A. (1984). In Toxigenic Fusarium Species: Identify and Mycotoxicology, The Pennsylvania State University Press, University Park.

11. Marasas, W.F.O., Nelson, P.E. and Toussoun, T.A. (1985). Taxonomy of toxigenic fusaria. In Trichothecenes and Other Mycotoxins (Lacey, J. ed.), John Wiley \& Sons Ltd., New York, pp. 3-14.

12. Naito, S. (1984). Studies on foliage blight of sugar beet. Res. Bull. Hokkaido Natl. Agric. Exp. Stn. 139 : 145-188 (in Japanese with English summary). 
13. Nakajima, T. and Abe, J. (1990). A method for assessing resistance to the snow molds, Typhula incarnata and Microdochium nivale, in winter wheat incubated at the optimum growth temperature ranges of the fungi. Can. J. Bot. 68 : 343-346.

14. Nakajima, T., Abe, J. and Nemoto, M. (1988). Seed transmission of pink snow mold and field observation of perithecia of Microdochium nivale. Ann. Phytopathol. Soc. Jpn. 54 : 90 (Abstr. in Japanese).

15. Nakajima, T. and Naito, S. (1994). Microdochium nivale, causal pathogen of Fusarium blight in cereals and pink snow mold, does not produce known mycotoxins. Ann. Phytopathol. Soc. Jpn. 60: 758 (Abstr. in Japanese).

16. Nakajima, T. and Nemoto, M. (1987). Relationship between wheat scab and pink snow mold. Tohoku Agric. Res. 40 : 119-120 (in Japanese).

17. Sugiura, Y., Fukasaku, K., Tanaka, T., Matsui, Y. and Ueno, Y. (1993). Fusarium poae and Fusarium crookwellense, fungi responsible for the natural occurrence of nivalenol in Hokkaido. Appl. Environ. Microbiol. 59 : 3334-3338.

18. Takeda, K. and Heta, H. (1989). Establishing the testing method and a search for the resistant varieties to fusarium head blight in barley (Hordeum vulgare). Jpn. J. Breed. 39 : 203-216.

19. Tanaka, T., Hasegawa, A., Matsuki, Y., Ishii, K. and Ueno, Y. (1985). Improved methodology for the simultaneous detection of the trichothecen mycotoxins deoxynivalenol in cereals. Food Addit. Contam. 2: 125-137.

20. Tanaka, T., Hasegawa, A., Yamamoto, S., Matsuki, Y., Ishii, K. and Ueno, Y. (1986). Productivity of Fusarium sp. Fn-2B for nivalenol and fusarenon-X on cereal substrates. Proc. Jpn. Assoc. Mycotoxicol. 24 : 60-62 (in Japanese with English summary).

21. Tatsuno, T., Saito, M., Enomoto, M. and Tsunoda, H. (1968). Nivalenol, a toxic principle of Fusarium nivale. Chem. Pharm. Bull. 16 : 2519-2520.
22. Ueda, S., Yoshizawa, T. and Nao, M. (1990). Production of Fusarium-Mycotoxins by dispersal ascospores of Gibberella zeae. Ann. Phytopathol. Soc. Jpn. 56 : 331-336 (in Japanese with English summary).

23. Ueno, Y., Ishikawa, Y., Saito-Amakai, K. and Tsunoda, H. (1970). Environmental factors influencing the production of fusarenon-X, a mycotoxin of Fusarium nivale Fn-2B. Chem. Pharm. Bull. 18 : 304-312.

24. Ueno, Y., Sato, N., Ishiii, K., Sakai, K., Tsunoda, H. and Enomoto, M. (1973). Biological and chemical detection of trichothecene mycotoxins of Fusarium species. Appl. Microbiol. 25 : 699-704.

25. Yasuoka, S. (1994). Outbreak of wheat scab caused by Fusarium nivale and yield loss of winter wheat in Tokachi, Hokkaido. Ann. Rept. Plant Prot. North Japan $45: 35-37$ (in Japanese).

\section{和 文 摘 要}

中島 隆・内藤繁男 : 日本産 Microdochium nivale のマイコ トキシン生産能の再評価

Microdochium nivale はマイコトキシン生産菌として知られ ていたが, nivalenolが初めて単離された Fn-2B 菌株の同定の 誤りが指摘され，本来の $M$. nivale のマイコトキシン生産能が 疑問視されているため日本の菌株について再検討した。5 種の 植物から伝染環に基づいて収集した分離後 2 年以内の 30 菌株 を供試し米培地で $20^{\circ} \mathrm{C} ・ 2$ 週間および $0{ }^{\circ} \mathrm{C} \cdot 50$ 日間，コムギ粒培 地で $20^{\circ} \mathrm{C} ・ 2$ 週間および $0{ }^{\circ} \mathrm{C} ・ 50$ 日間それぞれ培養した。また， コムギ穂に接種後 $20^{\circ} \mathrm{C} ・ 4$ 日間加湿した接種箱に静置したサン プル，固場から採取したオーチャードグラス紅色雪腐病の被害 茎葉も分析に供試した。その結果, 全ての菌株・培養法で既知の マイコトキシン (deoxynivalenol, 3-acetyldeoxynivalenol, nivalenol, fusarenon-X, T-2 toxin, neosolaniol, zearalenone) は検出されなかった。Fn-2B 菌株の菌糸生長温度は M. nivale より高温性で, Fn-2B 菌株は積雪下でコムギに対する病原性は なかった。 